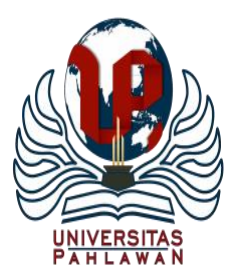

Jurnal Abdidas Volume 2 Nomor 4 Tahun 2021 Halaman 975-981

JURNAL ABDIDAS

http://abdidas.org/index.php/abdidas

\title{
Optimalisasi Kapasitas Fisik pada Siswa Sekolah Selama Pembelajaran Online
}

\author{
Siti Nadhir Ollin Norlinta ${ }^{1 凶}$, Rizky Wulandhari $^{2}$ \\ Fisioterapi, Universitas Aisyiyah Yogyakarta, Indonesia ${ }^{1,2}$ \\ E-mail : sitinadhirollin@unisayogya.ac.id $\underline{\text { rizkywulandhari@unisayogya.ac.id }}^{2}$
}

\begin{abstract}
Abstrak
Upaya yang dilakukan pemerintah dalam menangani wabah COVID-19 salah satunya dengan melakukan social distancing. Adanya kebijkan tersebut, sebagian besar sekolah di Indonesia menerapkan pembelajaran online. Bagi siswa pembelajaran online, tidak adanya interaksi dengan teman, tidak adanya kegiatan ekstrakulikuler dan kegiatan sekolah sehingga mengurangi kapasitas fisik siswa. Banyak siswa sekolah yang mengikuti pembelajaran online mengeluhkan berat badan naik dan mudah lelah. Rata-rata setiap siswa membutuhkan waktu untuk proses pembelajaran sekitar 5 jam sehari. Perubahan gaya hidup masa pembelajaran online mengakibatkan banyak remaja mengalami obesitas tingkat 1. Hal tersebut disebabkan karena kurangnya aktivitas fisik dan kelebihan kalori sehingga menimbulkan penumpukan lemak dalam tubuh. Memberi penyuluhan edukasi terkait bahaya obesitas serta pelatihan peningkatan kapasitas fisik siswa sekolah. Memberikan booklet berisi contoh latihan peningkatan kapasitas fisik sebagai buku panduan pada saat pelaksanaan pelatihan. Meningkatnya angka obesitas di Desa Pakem sebanyak 40\% berdampak pada meningkatnya Penyakit Tidak Menular (PTM), seperti diabetes, kanker, stroke, jantung, hipertensi dan gagal ginjal kronis. Untuk menghindari hal tersebut telah dilakukan pengabdian masyarakat berupa penyuluhan dan pelatihan aktivitas fisik. Setelah pelatihan tersebut, remaja Desa Pakem memulai menjaga pola hidup sehat dan rajin melakukan latihan fisik/olahraga. Pemberian latihan fisik dan penyuluhan edukasi bahaya obesitas memberikan manfaat dalam bidang ilmu pengetahuan, olahraga di rumah, serta kesadaran tentang pola hidup sehat.
\end{abstract}

Kata kunci: remaja, obesitas, aktivitas fisik

\section{Abstract}

One of the efforts made by the government in dealing with the COVID-19 outbreak is social distancing. With this policy, most schools in Indonesia implement online learning. For online learning students, there is no interaction with friends, there are no extracurricular activities and school activities, thus reducing the physical capacity of students. Many school students who take online learning complain of gaining weight and getting tired easily. On average, each student needs time for the learning process about 5 hours a day. Lifestyle changes during online learning have resulted in many adolescents experiencing level 1 obesity. This is due to lack of physical activity and excess calories, causing fat accumulation in the body. This method provide educational counseling related to the dangers of obesity and training to increase the physical capacity of school students. Provide a booklet containing examples of physical capacity building exercises as a guide book during training implementation. The increase in obesity rates in Pakem village by $40 \%$ has an impact on increasing Non-Communicable Diseases (NCDs), such as diabetes, cancer, stroke, heart disease, hypertension and chronic kidney failure. To avoid this, community service has been carried out in the form of counseling and physical activity training. After the training, the youth of the village of Pakem started to maintain a healthy lifestyle and were diligent in doing physical exercise/sports. The provision of physical exercise and education counseling on the dangers of obesity provides benefits in the fields of science, exercise at home, as well as awareness about a healthy lifestyle.

Keywords:teenager, obesity, physical activity

Copyright (c) 2021 Siti Nadhir Ollin Norlinta, Rizky Wulandhari

$\triangle$ Corresponding author

Address : Universitas'Aisyiyah Yogyakarta

Email : sitinadhirollin@unisayogya.ac.id

DOI $\quad:$ https://doi.org/10.31004/abdidas.v2i4.400
ISSN 2721- 9224 (Media Cetak)

ISSN 2721- 9216 (Media Online) 
976 Optimalisasi Kapasitas Fisik pada Siswa Sekolah Selama Pembelajaran Online- Siti Nadhir Ollin Norlinta, Rizky Wulandhari

DOI: https://doi.org/10.31004/abdidas.v2i4.400

\section{PENDAHULUAN}

Penderita Covid-19 di Indonesia sejak presiden mengumumkan ada penderita yang positif pada bulan Maret 2020, sampai sejauh ini jumlah penderita terus mengalami peningkatan. Beberapa sudah dinyatakan sembuh, beberapa meninggal dunia (Firdhy Esterina Christy, 2020).

Upaya yang dilakukan pemerintah dalam menangani wabah Covid-19 salah satunya dengan melakukan social distancing. Adanya kebijkan tersebut sebagian besar sekolah di Indonesia menerapkan pembelajaran online menurut himbauan dari Menteri Pendidikan dengan Nomor 15 Tahun 2020 yang menyarankan untuk belajar di rumah. Selain itu, ada larangan kegiatan tatap muka selama kegiatan belajar mengajar.

Sejumlah sekolah baik swasta maupun negeri mengeluarkan kebijakan untuk melakukan proses belajar di rumah dengan menggunakan berbagai metode pembelajaran menggunakan aplikasi online seperti Zoom, Google Meet dan WhatsApp Group. Jam pelajaran selama pembelajaran online tetap sama hanya saja setiap pertemuan dihitung 45 menit, berbeda dengan tatap muka dengan 60 menit setiap pertemuan. Rata-rata setiap siswa membutuhkan waktu untuk proses pembelajaran sekitar 5 jam sehari, dengan siswa fokus pada media pembelajaran online.

Selama belajar online bukan menjadi alasan bahwa tidak melakukan aktivitas apapun. Waktu yang padat seringkali siswa malas melakukan aktivitas dan waktu istirahat sering digunakan untuk bermain HP atau menonton TV. Aktivitas seperti ini jika dilakukan dalam jangka waktu yang lama tubuh akan mengalami penurun fungsi-fungsi motorik dan gangguan status gizi lebih. Karena tugas online dari sekolah terlalu banyak mengakibatkan para siswa terbiasa makan dengan kalori berlebih. Selama pembelajaran online kurang lebih satu tahun mereka tiba-tiba merasakan perasaan berat dalam berbagai aktivitas (Kementerian Pendidikan dan Kebudayaan, 2020).

Perubahan gaya hidup yaitu gaya hidup tradisional yang tergeser dengan gaya hidup milenial sehingga menyebabkan resiko terjadinya status gizi lebih semakin meningkat. Hasil studi yang dilakukan (Rahma E., Wirjatmadi, 2020) obesitas merupakan kelebihan gizi yang dapat dipengaruhi oleh berbagai macam faktor. Salah satu faktor yang mempengaruhi status gizi adalah aktivitas fisik. Asupan energi yang berlebihan dan tidak diimbangi pengeluaran energi yang seimbang (kurang melakukan aktivitas fisik) akan menyebabkan terjadinya penambahan berat badan badan. Aktivitas fisik sangat diperlukan untuk menjaga berat badan ideal dan kebugaran tubuh.

Perubahan gaya hidup mengakibatkan terjadinya pola makan masyarakat yang merujuk pada pola makan tinggi kalori lemak dan kolesterol dan tidak diimbangi dengan aktivitas fisik ringan. Pada saat latihan ringan dengan intensitas dan durasi latihan, terjadi peningkatan jumlah leukosit dalam darah (limposit dan neutropil) serta trombosit. Terjadi pula peningkatan konsentrasi plasma dikenal dengan efek fungsi leukosit.

Permasalahan mitra di sini di Dusun Pakeran, Kelurahan Sendang Mulyo. Banyak siswa sekolah yang mengikuti pembelajaran online mengeluhkan tiba-tiba berat badan bertambah dan badan terasa berat ketika akan melakukan aktivitas 
977 Optimalisasi Kapasitas Fisik pada Siswa Sekolah Selama Pembelajaran Online- Siti Nadhir Ollin Norlinta, Rizky Wulandhari

DOI: https://doi.org/10.31004/abdidas.v2i4.400

baik ringan, sedang sampai berat. Tubuh yang cenderung diam dan kurang bergerak berpengaruh pada imunitas.

\section{METODE}

Prosedur pelaksanaan pengabdian masyarakat ini terbagi dalam 3 tahap:

Koordinasi dengan warga Dusun Pakeran RT 2 RW 13, dengan melakukan pertemuan untuk memberikan penjelasan tentang latihan kapasitas fisik bagi siswa selama pembelajaran online dan penjelasan materi edukasi yang berhubungan dengan obesitas. Pelaksanaan kegiatan dilaksanakan secara online dengan media Zoom, kemudian dilanjutkan secara tatap muka dengan menerapkan protokol kesehatan yang sudah ditetapkan di rumah Pak RW Dusun Pakeran, Kecamatan Minggir.

Kegiatan pelatihan meliputi penyampaian materi edukasi pencegahan obesitas dan latihan optimalisasi kapasitas fisik. Kegiatan ini dilakukan secara online melalui Zoom. Pelaksanaan pelatihan dilaksanakan selama 3 kali dalam satu Minggu, hari pertama melakukan pengenalan program serta pemaparan materi tentang latihan fisik, edukasi pencegahan obesitas, dan pembagian booklet latihan. Hari kedua melakukan praktik latihan fisik. Hari ketiga melakukan secara mandiri latihan fisik sesuai dengan booklet yang sudah diberikan.

Kegiatan terakhir adalah evaluasi. Evaluasi di sini dimaksudkan untuk meninjau keberhasilan dalam melakukan latihan aktivitas fisik serta tanya jawab apabila selama melakukan aktivitas fisik timbul gejala atau rasa tidak nyaman yang dirasakan dalam tubuh. Pengukuran keberhasilan ini dengan membagikan kuesioner responden yang berisi nama, usia dan keluhan sebelum dan sesudah latihan.

\section{HASIL DAN PEMBAHASAN}

Kegiatan pengabdian masyarakat ini dilaksanakan untuk membagi pengetahuan kepada siswa sekolah yang sedang mengikuti pembelajaran online dan kader pemuda desa, sebagaimana yang tertuang pada Tridharma Perguruan Tinggi. Penyuluhan diberikan pada kader dengan harapan dapat tularkan kepada masyarakat sekitarnya, selain itu kepada siswa dan pemuda yang ada di RT 02 RW 13 dengan harapan dapat diaplikasikan secara aktif. Penyuluhan ini mengenalkan pengetahuan kepada kader pemuda dan siswa di RT 02 RW 13 pentingnya latihan fisik dan pencegahan dari obesitas.

Pada masa pandemi Covid-19, ada istilah baru di masyarakat yang disebut new normal. New normal adalah adaptasi kebiasaan baru, artinya beraktivitas dengan menerapkan protokol kesehatan (memakai masker, menerapkan pola hidup bersih dan sehat, menghindari kerumanan dan lain-lain). Diberlakukannya adaptasi kebiasaan baru untuk mencegah peningkatan kasus positif Covid-19 semakin membuat penggunaan teknologi, dan semua arus gaya hidup, globalisasi, industrialisasi semakin masif. Semua orang dapat berbelanja, memenuhi kebutuhan hidup dan beraktivitas dengan tetap di rumah, kalaupun harus keluar rumah dengan meminimalisir pertemuan dengan orang lain. Semua sekolah membatasi untuk tatap muka dan diberlakukan belajar melalui daring (Arinda, 2021). 
978 Optimalisasi Kapasitas Fisik pada Siswa Sekolah Selama Pembelajaran Online- Siti Nadhir Ollin Norlinta, Rizky Wulandhari

DOI: https://doi.org/10.31004/abdidas.v2i4.400

Kegiatan pengabdian masyarakat yang pertama meliputi paparan materi edukasi pencegahan obesitas serta latihan optimalisasi kapasitas fisik. Menurut definisi WHO, obesitas adalah penumpukan lemak yang berlebih atau abnormal yang dapat mengganggu kesehatan. Peningkatan obesitas selama pandemi COVID-19 disebabkan karena kurangnya aktivitas fisik selama pandemi dan keadaan klinis yang meningkatkan risiko peningkatan berat badan. Aktivitas masyarakat yang dibatasi selama pandemi ternyata berdampak pada penurunan aktivitas fisik. Contohnya pembelajaran jarak jauh (daring) bagi siswa sekolah yang menggunakan teknologi Zoom Meeting sehingga membuat para siswa tidak aktif bergerak dan hanya berkutat di depan laptop sepanjang hari (Alifa, 2021).

Selain karena penurunan aktivitas fisik, penurunan status ekonomi juga dapat meningkatkan risiko obesitas. Hal ini disebabkan karena bahan makanan yang terjangkau sebagian besar mengandung karbohidrat dan lemak yang tinggi sehingga meningkatkan risiko kegemukan. Faktanya angka obesitas di Indonesia memang cukup tinggi. Berdasarkan data Riskesdas 2018, angka obesitas di Indonesia mencapai 21,8 persen dimana angka ini terus beranjak naik sejak Riskesdas 2007 sebesar 10,5 persen dan 14,8 persen pada Riskesdas 2013 (UNICEF, 2021).

Menurut data pengabdian yang diperoleh di Dusun Pakeran dari sejumlah anak remaja yang sedang menjalani sekolah daring didapatkan hasil sekitar 40\% mengalami kenaikan berat badan dan kalau dihitung dengan BMI kategori obes class 1 diusia rata-rata 18 tahun. Kenaikan berat badan dilihat dari hasil pengisian presensi yang telah disebar melalui Google Form.

Berikut ini merupakan perhitungan BMI di usia rata-rata 18 tahun sebagai berikut:

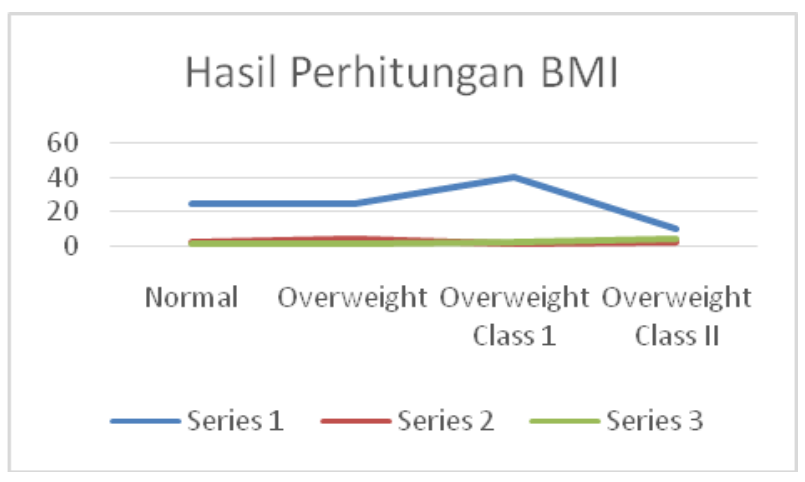

Gambar 1 Grafik BMI

Meningkatnya angka obesitas berdampak pada meningkatnya Penyakit Tidak Menular (PTM), seperti diabetes, kanker, stroke, jantung, hipertensi dan gagal ginjal kronis. Obesitas dapat memperburuk kondisi kesehatan terutama saat pandemi saat ini. Menurut penelitian dari University of North Carolina, obesitas dapat meningkatkan risiko kematian akibat COVID-19 hingga 48 persen dan berdampak pada efikasi vaksin COVID-19 yang tidak optimal. Obesitas juga meningkatkan risiko kondisi yang parah pada orang yang terkena COVID seperti berisiko menjalani perawatan terkait infeksi COVID tiga kali lipat (Pranishita, 2021).

Dari hal tersebut maka dalam pengabdian masyarakat menyampaikan untuk menjaga berat badan di masa pandemi kali ini harus bisa menjaga pola makan dan olahraga untuk optimalisasi aktivitas fisik. Hal tersebut berguna untuk mencegah Penyakit Tidak Menular (PTM) dan memperbaiki pola hidup di masa depan. 
979 Optimalisasi Kapasitas Fisik pada Siswa Sekolah Selama Pembelajaran Online- Siti Nadhir Ollin Norlinta, Rizky Wulandhari

DOI: https://doi.org/10.31004/abdidas.v2i4.400

Aktifitas fisik yang bisa dilakukan selama di rumah meliputi: pemanasan, inti dan pendinginan. Dalam pengabdian masyarakat sudah dibagikan booklet yang berisi 10 gerakan selama di rumah untuk optimalisasi kapasitas fisik, Berikut ini merupakan booklet sebagai panduan untuk melakukan aktivitas fisik.

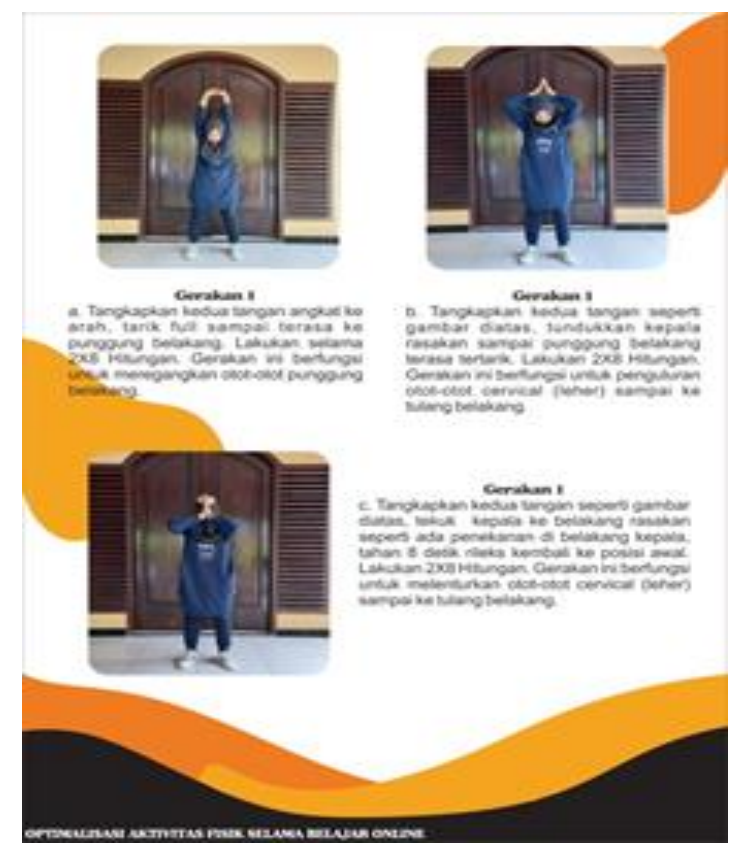

Gambar 2 Pembagian Booklet Aktivitas Fisik

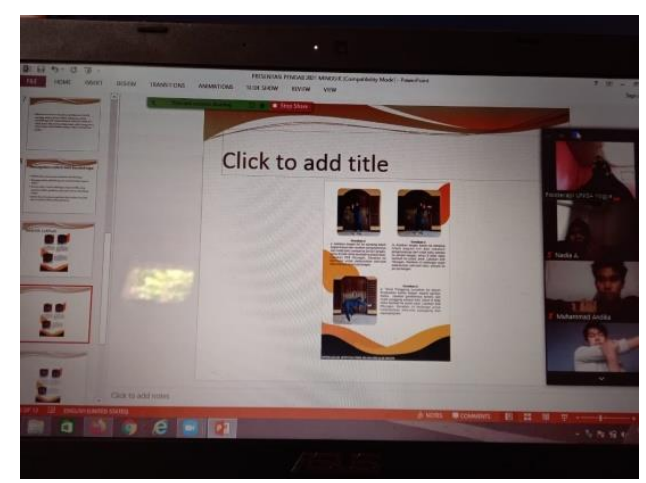

Gambar 3 Pemaparan Materi Aktivitas Fisik

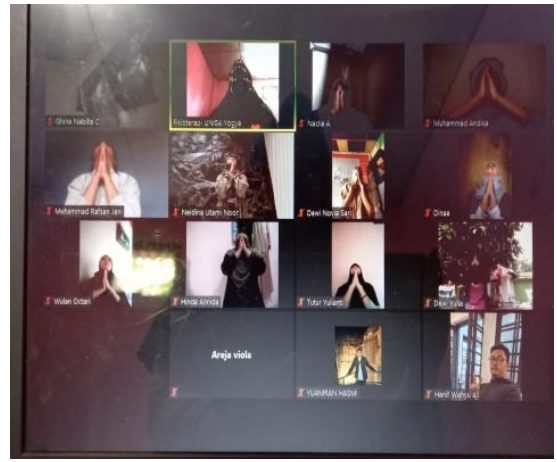

Gambar 4 Pelatihan Aktivitas Fisik

Olahraga/aktivitas fisik bertujuan untuk memelihara dan meningkatkan derajat kesehatan. Aktivitas fisik apabila dilakukan secara teratur memiliki efek yang luar biasa terhadap kesehatan di antaranya menjaga tubuh dari lemak yang berlebihan, meningkatkan mood, mengurangi hormon stress dan mengurangi peradangan pada persendian.

Lakukan aktivitas fisik dengan intensitas rendah terlebih dahulu. Aktivitas fisik seperti berjalan dapat dilakukan selama 5-10 menit, kemudian sedikit demi sedikit ditingkatkan sampai 30 menit sekali kegiatan. Lebih aman dan lebih baik untuk melakukan aktivitas fisik dalam waktu yang singkat dan diulang dari pada langsung melakukan aktivitas fisik dalam waktu yang lama. Lakukan aktivitas dengan baik untuk mengurangi risiko cedera. Lakukan aktivitas yang anda sukai. Pilihlah aktivitas yang sesuai dengan kondisi kesehatan dan kebugaran. Aktivitas fisik yang dilakukan dalam intensitas ringan-sedang akan membuat kita tetap dapat bernapas dengan nyaman dan masih dapat melakukan percakapan (Chen et al., 2020).

Hasil dari pengabdian masyarakat yang sudah dilakukan dilihat dari pengisian Google 
980 Optimalisasi Kapasitas Fisik pada Siswa Sekolah Selama Pembelajaran Online- Siti Nadhir Ollin Norlinta, Rizky Wulandhari

DOI: https://doi.org/10.31004/abdidas.v2i4.400

Form yang sudah diisi menunjukkan grafik sebagai berikut:

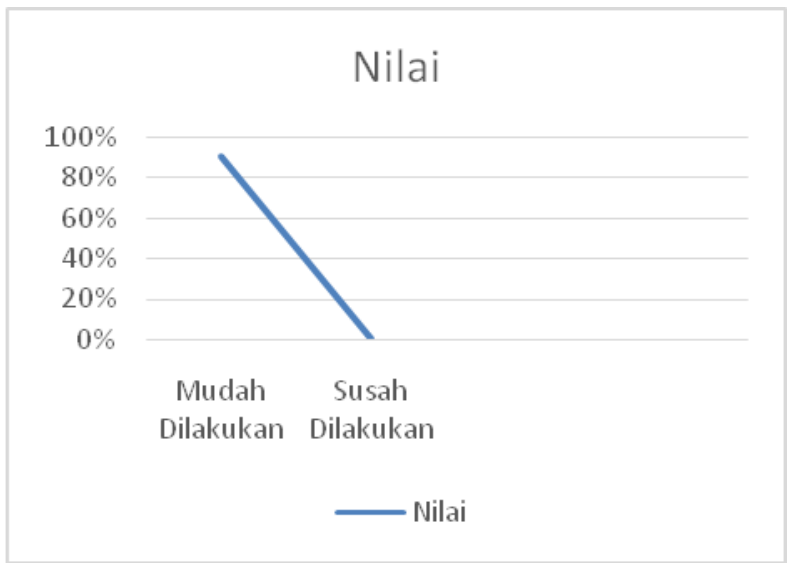

Gambar 5 Grafik Evaluasi Peserta

Dari data tersebut dapat disimpulkan untuk melakukan gerakan aktivitas fisik serta durasi dan dosis latihan dalam aktivitas fisik bisa diterima dengan baik sehingga peserta dapat melakukan ulang ketika pengabdian sudah selesai. Ketika keluar rumah atau tempat umum untuk melakukan aktivitas fisik, selalu terapkan memakai masker, menjaga jarak, cuci tangan dengan sabun dan air mengalir atau gunakan hand sanitizer sebelum pergi. Kita dapat melakukan aktivitas fisik dengan memperhatikan protokol kesehatan dan prinsip pencegahan dan pengendalian infeksi dengan baik.

\section{SIMPULAN}

Hasil kegiatan pengabdian masyarakat yang telah dilaksanakan dan sudah dijelaskan sebelumnya, maka dapat disimpulkan bahwa kegiatan pengabdian masyarakat ini menambah pengetahuan dan keterampilan dalam menerapkan hidup sehat dengan menjaga pola makan yang sehat untuk menghindari obesitas dan melakukan kegiatan olahraga/aktivitas fisik sehari-hari untuk menjaga kesehatan selama melakukan pembelajaran online. Kegiatan ini berdampak positif bagi Remaja yang menginjak usia dewasa setelah terlaksananya pengabdian masyarakat ini. Selanjutnya berdasarkan saran dan masukan dari kuesioner yang dibagikan perlu adanya pengembangan pelatihan pada remaja untuk menjaga kesehatan yakni pemberdayaan kader posyandu untuk remaja yang perlu diperhatikan asupan makanan, lingkungan yang bersih, keluarga sehat dan olahraga yang tepat untuk remaja.

\section{UCAPAN TERIMA KASIH}

Demikian pengabdian masyarakat yang sudah kami lakukan, tidak lupa ucapan terima kasih kami haturkan kepada:

1. Pihak pemberi dana dalam pengabdian masyarakat ini.

2. Pihak yang sudah memberikan arahan untuk melancarkan pengabdian masyarakat pada musim pendemi ini.

3. Perangkat desa dan jajarannya serta Masyarakat Desa Karangbangun Matesih yang sudah memberikan kesempatan dan meluangkan waktunya untuk mengikuti program pengabdian masyarakat yang kami lakukan.

4. Semua anggota pengabdian masyarakat yang tidak bisa disebutkan satu per satu yang sudah mensukseskan program pengabdian masyarakat dalam masa pendemi kali ini.

5. Semua keluarga saya dan keluarga anggota yang turut memberi dukungan sampai 
981 Optimalisasi Kapasitas Fisik pada Siswa Sekolah Selama Pembelajaran Online- Siti Nadhir Ollin Norlinta, Rizky Wulandhari

DOI: https://doi.org/10.31004/abdidas.v2i4.400

selesai pelaksanaan pengabdian masyarakat

kali ini.

Alhamdulillah semoga dengan selesainya pengabdian masyarakat ini dapat membawa keberkahan untuk diri sendiri dan semuanya. Mohon maaf apabila selama pelaksanaan pengabdian masyarakat terdapat perbuatan dan salah kata baik disengaja maupun tidak disengaja.

\section{DAFTAR PUSTAKA}

Alifa, S. (2021). Urgensi Penanganan Stunting dan Obesitas di Era Pandemi COVID-19 | Puspensos. Retrieved August 16, 2021, from https://puspensos.kemensos.go.id/urgensipenanganan-stunting-dan-obesitas-di-erapandemi-covid-19

Arinda, D. F. W. D. dan Y. (2021). View of AKTIVITAS FISIK, PERILAKU KESEHATAN DAN GIZI DI MASA NEW NORMAL PADA PEGAWAI DI INDONESIA. Retrieved from http://journal.binawan.ac.id/JAKAGI/article/ view/154/131

Chen, P., Mao, L., Nassis, G. P., Harmer, P., Ainsworth, B. E., \& Li, F. (2020, March 1). Coronavirus disease (COVID-19): The need to maintain regular physical activity while taking precautions. Journal of Sport and Health Science. Elsevier B.V. https://doi.org/10.1016/j.jshs.2020.02.001

Firdhy Esterina Christy. (2020, March). Perkembangan Kasus Covid-19 di Indonesia (24 Maret 2020. Majalah Tempoe. Retrieved from

https://data.tempo.co/data/643/perkembangan -kasus-covid-19-di-indonesia-24-maret-2020

Kementerian Pendidikan dan Kebudayaan. (2020). Kemendikbud Terbitkan Pedoman Penyelenggaraan Belajar dari Rumah $29 \mathrm{Mei}$ 2020. SIARAN PERS Nomor: 128/Sipres/A6/V/2020. Retrieved from https://www.kemdikbud.go.id/main/index.ph $\mathrm{p} / \mathrm{b} \log / 2020 / 05 /$ kemendikbud-terbitkanpedoman-penyelenggaraan-belajar-darirumah
Pranishita, A. K. (2021). Ahli gizi: Waspadai potensi obesitas saat pandemi COVID-19 ANTARA News. Retrieved August 16, 2021, from https://www.antaranews.com/berita/1733430/ ahli-gizi-waspadai-potensi-obesitas-saatpandemi-covid-19

Rahma E., Wirjatmadi, B. (2020). Hubungan antara Aktivitas Fisik dan Aktivitas Sedentari dengan Status Gizi Lebih pada Anak Sekolah Dasar. IAGIKMI \& Universitas Airlangga, 79-84.

https://doi.org/10.2473/amnt.v4i1.2020. 7984

UNICEF. (2021). COVID-19 dan Anak-anak di Indonesia | UNICEF Indonesia. Retrieved August 16, 2021, from https://www.unicef.org/indonesia/id/laporan/ covid-19-dan-anak-anak-di-indonesia 